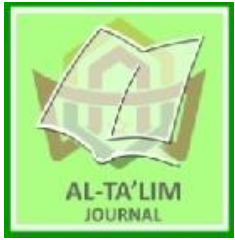

AL-TA'LIM JOURNAL, 27 (2), 2020, (192-207)

(Print ISSN 1410-7546 Online ISSN 2355-7893)

Available online at http://journal.tarbiyahiainib.ac.id/index.php/attalim

\title{
Family Education Efforts in Overcoming Juvenile Delinquency
}

Received: $29^{\text {th }}$ September 2019; Revised: $28^{\text {th }}$ March 2020; Accepted: $30^{\text {th }}$ July 2020

Permalink/DOI: http://dx.doi.org/10.15548/jt.v27i2.595

\begin{abstract}
Ahmad Putra*)
Universitas Islam Negeri Sunan Kalijaga

Yogyakarta, Indonesia.

E-mail: ahmadputra752@yahoo.com
\end{abstract}

\section{Yulia Fitria}

Nanchang University, Tiongkok

E-mail: ulifitri11@gmail.com

\section{Bima Prasetya}

Universitas Padjadjaran, Bandung,

Indonesia.

E-mail: bmaprstya@gmail.com

\begin{abstract}
This article discusses the education that families provide to children in overcoming various forms of delinquency carried out by juveniles in Karang Tangah village, West Sumatra. It is believed that the family is the main pillar that shapes the personality and attitude of a child. Thus, it really needs attention and primary teaching from the family so that children avoid the influence of technological advances that could have pushed every child (juveniles) involved in various forms of mischief. Along with the times and technology, without us knowing so much it is heard that children or juveniles are involved in mischief's they are not supposed to do that will only harm themselves. Therefore, this research will describe the various forms of delinquency that juveniles do and of course, there are efforts and efforts of parents in looking after their children. It is hoped that parents can take care of and educate their children well.
\end{abstract}

Keywords: Education; family; delinquency; juvenile

How to Cite: Putra, A., Fitria, Y., \& Prasetya, B. (2020). Family Education Efforts in Overcoming Juvenile Delinquency. Al-Ta lim Journal, 27(2). doi:https://doi.org/10.15548/jt.v27i2.595

\section{INTRODUCTION}

Family education is a major provision that parents must strive to provide teaching to their children. In terms of the core, of course the family must have certain ways in educating children, so that how children can grow and later contribute to society. This is in line with what was said by one of the figures named Mansur, that family education is a process where the giving of positive values from the family to children in the hope that children can grow well and later be able to become the foundation in his life journey. (Gee, 2000; Hein, 2005; Liñán dkk., 2011; Mansur, 2005; Thomas, 2002).

Abdullah (2003) said that family education is all forms of business and efforts made by parents both learning to familiarize children and to help develop the child's personality to better progress. Likewise with what was conveyed by Berns (2004), that the family is a fellowship of life that is woven with affection between the couples in it who are passed through marriage to perfect each other. So, with the formation of a bond of affection through marriage, formed the name obligations that must be carried out by parents for their children (Damerell dkk., 2013; Eccles, 2005; Semba dkk., 2008).

The form of obligation from parents to children is first, the obligation to care for the outer covering health, eating and drinking that is halal-thayyibat, as well as other physical needs. Second, the obligation to maintain the inner life which includes comfort and peace, and education as a preparation for his life behind the day (Corso \& Lanz, 2013; Nizar, 2008; Silverstein dkk., 2006). This was also there are seven obligations of parents towards 
children, namely the responsibility of faith education, moral education, physical education, intellectual education, psychological education, social education and sexual education (Boonstra, 2001; Franceschelli \& O’Brien, 2014; Hasna, 2003).

Obligation of parents to children above is an effort in shaping the attitudes and morals of children who really avoid delinquents and who can tarnish the image of the family. But the most important of all is how parents can educate children to have the right character so that what they do remains classified as moral mercy (praiseworthy) (Berkowitz \& Hoppe, 2009; Brannon, 2008; Pamungkas, 2012). So with that, every parent must equip their children with the right and proper upbringing. Parents need to understand what kind of development can be done for the growth of children and with it will also be able to see how the child's potential (Damon, 2004; Jamison, 2005; Walker dkk., 2015).

In addition, parents must know that there are several psychological features in adolescents, including: First, juvenile delinquency includes all behaviors that deviate from the norms of criminal law committed by adolescents. This behavior will be detrimental to him and the environment in which he lives. Second, there are many causes that make teens enter the world of free/ broken relationships. It begins with making friends with peers who are used to bad behavior so that children become easily influenced by the situation. Third, the thing that causes teenagers to be easily involved in the form of delinquency is the lack of strengthening of religion possessed by children, so there is no awareness to behave properly in carrying out an action (Lestari dkk., 2017). Thus, children really need religious education, of course, how families provide a good education for children because everything is in the family.

As the times and technology develop, it makes it easier for teens to get involved in delinquency. This mischief certainly disturbs the community and is embarrassing for the area where he lives. They do it with the intention to be known, recognized and like there is competition with peers. Therefore, the family as the main place of education must be able to form a sense of security and comfort for children in learning to improve themselves with values of kindness (Eccles \& Roeser, 2009; Van Zanten, 2005; Wößmann, 2003; Yüksel \& Coşkun, 2013). Besides that, do not let the development of the times bring adolescents to a situation that makes matters worse, so that they can become naughty and confronted with violations in which children will be faced with severe sanctions (Mincey dkk., 2008).

As far as, Karang village community is known to be quite active in religious activities, such as enlivening mosques, active in Islamic activities, mauled Prophet Muhammad SAW and reciting when one of the people died. Karang village community also many who get education up to lectures and some teenagers there are also religious schools. The problem is, some parents are still careless in supervising children's activities because parents are busy with their work and there are also some parents who work abroad so that they are unable to monitor children's development.

Based on the description above, it can be concluded that the importance of the role of parents, community and government in supervising and guiding children and adolescents, especially in carrying out the age filled with the problems they face. Need attention so that adolescents are not involved in deviations that will only harm themselves.

Based on the context and phenomena above, the writer finds it interesting to explore so that he knows what juvenile delinquency is happening and the efforts of parents to children in Karang Tangah Village, Lengayang Subdistrict, Pesisir Selatan Regency, and West Sumatra.

\section{METHOD}

This research uses a qualitative approach with qualitative descriptive analysis that describes systematically factually and accurately about facts, situations or events. According to Denzib and Licolin as quoted by 
Moleong explained that qualitative descriptive research is research that uses scientific background with the aim of describing phenomena that occur and are carried out by involving various existing methods (Moleong, 2010).

Data obtained through observation is a research carried out systematically and deliberately carried out by using the senses, especially the eyes of events that can be captured when the incident took place (Walgito, 2010). In this case, the interview was also conducted by involving several teenage parents who were involved with delinquency, thus corroborating the data in the research that the author conducted.

Then the interview technique is a meeting of two people to exchange information and ideas through question and answer. The interview in this study is a guided free questions but in accordance with the data to be examined (Amani, 2018).

\section{RESULT AND DISCUSSION}

\section{Education and Family}

Education is very instrumental in human life, if there is no education then all aspects of human life will not stand firm. It is education that tries to direct all human steps to be able to carry out the tasks of life that are lived everyday (Ira, 2008). Education aims to make people who are knowledgeable and good about faith and devotion to God Almighty, so that he will play a good role both for his parents, family and the State.

According to Fransisca (2009). said that education comes from the basic word "educator" which means to maintain and provide training. Both of these require the existence of teachings, guidance, and leadership about the intelligence of the mind. Understanding education is the process of changing the attitudes and behavior of a person or group of people in an effort to mature humans through teaching and training efforts. By seeing this definition, some people define education as teaching because education generally requires teaching and everyone has an obligation to educate. Narrow teaching is the activity of formally conveying subject matter so that students master the teaching material.

In essence, education has two goals: helping people to be smart and smart and helping them to become good human beings. Making humans to be smart and smart is not a difficult thing, but forming a good human being on all sides experiences a process that is not easy (Sudrajat, 2011). In realizing an education that is quality and efficient, efforts need to be made that are able to make people who are invited to move themselves to achieve a change. So with that, truly create knowledgeable people, educated and superior in human resources (Romlah, 2016). Education is given to every child, very much determines how the character of the child, including morale. Good moral every child will be a strong foundation for himself in dealing with various problems of life and the life he lives (Muhammad, 2003).

\section{Family}

Etymologically the family in Javanese terms consists of two words namely servant and citizen. Kawula means servants and residents are members. This means a collection of individuals who have a sense of selfless devotion for the benefit of all individuals who are involved in it. The family is a group characterized by shared housing, economic cooperation, and reproduction that is united by marriage relationships or socially agreed adoption, which interact with each other according to their social roles (Aziz, 2015).

According to Taubah, the family is the main forum that plays a role in educating children. So the awareness and enthusiasm of parents in educating children is very important and self-determination of children in the future. As the Prophet said: The Prophet Muhammad (PBUH) said: every baby born is natural, then both parents make him Jewish, Christian or Majusi (HR. Bukhari) (Baharun, 2016; Jailani, 2014; Taubah, 2015) 
Ramayulis (2001) said that the family will be bound by two important relationships, namely the existence of ties due to blood relations and marital relations. Family is defined as a collection of people who live together with a place to live together and each person involved in it feels an inner connection so that the values of beauty, mutual care, and mutual help and care for fellow family members (Berns 2007)

The family is also the smallest unit responsible for creating a peaceful and civilized society. Therefore, the family must become a protected fortress. The family is the smallest unit in society consisting of husband and wife, or husband and wife and children, or father and child, or mother and child, or family in a straight line up or down to the third degree (PerpustakaanNasional RI 2009). The role of the family in shaping each child is very good for each child, even the role of the family is not much different from the role of the school in providing education, especially from father and mother (Mahmud, 2000; Mahmud, 2012). With family upbringing, children will be able to avoid behaviors that will make them frustrated so that it is easy to participate in various deviations, so that with education the child will have a concern with his social situation (Reinke dkk., 2009).

The family is the smallest social unit consisting of husband and wife and if there are children and are preceded by marriage. From this understanding means the absence of a child does not abort the family status, so the child's factor is not an absolute factor for realizing a family. A family that happens to be not blessed with children, still has family status (Ahmadi, 2002). The family is a natural nurturing place that protects a new child from growing up and caring for him, as well as developing his physical, intellect and spirituality. In the family umbrella, feelings of love, empathy, and solidarity are combined and united. Children will do what has usually attached all their lives. Then with family direction and direction, the child will be able to welcome life, understand the meaning of life and its purpose, and know-how to interact with living things (Khayyal, 2005).
The pair of words from the family is happy, so the idiom becomes a happy family. Meaning, the goal of every person who fosters the home is looking for happiness in life. If someone fails in his career outside the home, but succeeds in building a strong and prosperous family, then he is still seen as a successful and happy person. Conversely, people who are successful outside the home, but the family is broken, so he is not called a lucky person, failure in his household will be reflected on his face, also reflected in his unhappy lifestyle (Mubarak, 2016).

The family is the first place used by children as the first place to complain about anything; therefore the family function is prioritized for children. Children will be of good character if parents educate them well. But if parents or siblings do not play a role in children's education, then the child does not feel that there is something to obey and follow but will go through what he wants and his own mindset. The family is obliged to think about the child's success, not just leave life without good direction and guidance. Families are also the most important primary group in society. A family is a group formed by the relationship between men and women, a relationship which is more or less lasting to create and raise children. So the family in its pure form is a social unit consisting of husband and wife and children who are not yet mature. This unit has certain characteristics in common, everywhere in the unit of human society (Aziz \& Hartono, 2001).

The family as a smaller social subsystem, or as a condition for the family to survive, these two kinds of systems must be interconnected in many ways, both of which are relationships between family members and relationships between families and the community (Goode, 2007). The family is the smallest institution that has an extraordinary role in educating children, especially regarding morals. If a family provides a correct and purposeful education, then the child will be able to be a useful person for the people around him (Qaimi, 2002). 


\section{The Purpose of Family Formation}

The family is a structure in society that is special, mutually binding to one another. According to Islamic teachings both contain responsibilities and a sense of mutual ownership and mutual expectation. The value of compassion based on religion makes the structure of the family have a solid foundation. In contrast to modern society which tends to think and behave pragmatically, so marriage is preferred as a sexual, reproductive and recreational function. The family system that is recognized by Islam is "al-usrahazzawjiyyah" (husband and wife), which is a family consisting of husband, wife and children who are not married. Married children are seen as having made a family too. The bond of kinship in an Islamic family is not only for the father, or the mother only, but for the father and mother as well, even though the emphasis is on the father (Bafadhol, 2017)

In language, the origin of the word marriage is na-ka-ha meaning Indamma (joining), jama'a, wata'un (sexual relations), 'aqdun (agreement) (Syarifuddin, 2006). While the terminological meaning of marriage: "A contract or agreement that contains the purpose of allowing sexual relations by using lafadz na-ka-ha or za-waja" (Departemen Agama RI, 2008). Mukarrom defines marriage as an aqad with which it becomes halal sexual relations between men and women (Mukarrom, 2018). Whereas Nashuddin (2015) interpreted it as a sacred, strong and solid agreement to live together legally between a man and a woman to form a family that is eternal, polite, loving, loving, peaceful and happy. Marriage is not only intended to have sexual relations and give birth to offspring but more than that, namely to meet human needs from the spiritual side, namely to form a family sakinah based on mawaddah and rahmah.

\section{Family Functions}

The family has a very important role in shaping the behavior and emotional development of children, therefore the family must be able to carry out its functions properly by meeting the needs of children both physiological and psychological. The basic function of the family is to provide a sense of belonging, security, affection, and develop a good relationship between family members (Yusuf, 2009). The main task of the family as an important aspect of children's education is to lay the foundation for instilling true character and personality in accordance with Islamic teachings (Baharun, 2016).

The family environment is considered as the main and first distributor for the child, especially in terms of education. If education is not provided, then the family is to blame because it can make the child worse off in the family, community and in the world of education at school. So with that, it is the family that becomes an important aspect in shaping the child's self. A successful family is a family that is able to form a generation of moral and noble character, so that the generation is able to be directed to the right personality. If the family is wrong in educating, then it is certain that the child will cause disaster to the family and society, especially for both parents (Al-Hasyimi, 2004).

The role of the family is first and foremost basic. He is the foundation that will be very influential for further formation. If the coaching can be carried out well, then it can be assumed that the coaching has been able to lay a solid foundation for the next level of education, namely coaching in the school and community environment (Al Munawar, 2005). In addition, with the socialization function, it is expected that children will get protection from various threats and with the assistance of education from families and schools so that children's behavior can be controlled. So with that, there needs to be joint support (Kim dkk., 2005).

The function of the family in society is an institutional structure that develops through community efforts to accomplish certain tasks. Parents are actually the key to children's motivation and educational success. No other party will be able to completely replace the role of parents. The success of 
parents in supporting motivation and success in education lies between the close relationship between parents and their children.

Sudjana (2004) expressed a number of family functions, including: first, biological functions, namely maintaining the physical body of fellow family members and fulfilling sexual needs. Second, the educational function, namely the family as a place of education for members in the family. Third, the religious function, the family becomes the main place in introducing children and family members about religious knowledge. Fourth, the function of affection, the family needs to instill loving care with family members. Fifth, the function of protection, the family must together take care of one another. Sixth, the function of socialization, the family becomes a forum that educates and teaches children with things that are outside the home. Seventh, Economic functions, the family becomes a container in introducing children that the need to make a living. Eighth, recreational function, where the family becomes a container in making all family members feels comfortable and happy. Ninth, the function of caring, the family becomes a place to teach one another the need to care for others and the environment. The role of family and community is very interesting if it is carried out in the same axis, which is both aimed at encouraging good results in children. Therefore, there is a need for proper education between families and the community.

\section{Education in the Family}

\section{The Purpose of Religious Education in the Family}

Mahmud's (2013) quote, stated that the goal of Islamic education in the family is to educate and nurture children to become adults who have a noble mentality and morality responsible both morally, religiously and socially. Education pursued by a family in overcoming juvenile delinquency is certainly related to improving the child's morals. Morals really determine the identity and development of children wherever he is. al Utsaymin mentioned that morals include relations with al-Khaliq and interactions with beings (Muzaqi dkk., 2019). Education in the family provides knowledge and religious skills, and moral values for each person specifically for the child to be able to play the right role both when with family and with the wider community (Mizal, 2014).

Some studies explain that education provided by the family to children with the right goals will keep children from worrying bad risks. It is the family factor that determines it all and becomes an effort that can nurture the behavior and resilience of children in undergoing the daily processes they do (Reynolds, 2010).

Miskawaih said that what needs to be instilled in children and adolescents first are shame. In accordance with one of the hadiths of the Prophet from Abu Mas'ud radhiyallahu 'anhu, Rasulullah said: "Indeed, some of the teachings that are still known to mankind from the words of the previous Prophets are:' If you are not ashamed, do as you please. " (Narrated by Al Bukhari)

The obligation of parents is to educate children well, pay attention, and support children's education to be better, provide a high level of attention and give good examples to their children. It is also necessary to care for parents based on love and care for children and consider the importance of educating their children, and fostering children to control their children from bad influences. Education to children cannot be separated from three things, namely family, school, and community. The success of education in a country or region depends on these three factors (Damerell dkk., 2013; Qadar Muhammad, 2011).

\section{Obligations of Parents}

Since in the womb, according to the scholars, children can have rights even though they have not received obligations. The rights possessed by children in the womb include, among others, inheritance rights, testamentary rights, and the right to own property (Departemen Agama RI, 2008). This shows that the parents' affection must be given since 
the child is still in the womb, both in the form of care or monitoring the physical health of the fetus and its acceptance of its psychological presence (S. Aziz, 2015). That is why in Islam, children from the womb until they reach adulthood have the right to care and care (hadanah) which must be carried out by their parents.

Roesli et al, 2018) said that "One of the inherent obligations and rights of parents is to educate children and because parents give life to children and they have the most important obligations to educate their children. Thus parents have the obligation to care for, nurture and educate children, starting from preparing for pregnancy, checking the health of the fetus, giving birth safely, caring for, caring for, and supervising its development, and educating it to be a healthy, godly, and knowledgeable child. For this reason, Islam has a good and strong future generation. Allah says:

"And let those [executors and guardians] fear [injustice] as if they [themselves] had left weak offspring behind and feared for them. So let them fear Allah and speak words of appropriate justice.” (QS. An-Nisa: 9).

As a consequence of this hadanah, parents (especially fathers) have an obligation to provide for their children. Because the gift is not possible to run well without the existence of living in the form of food, clothing, shelter, and other tourist facilities so that children grow and develop properly. It can even be said that the liability for these children is still part of the hadahah because the Hadahah is the maintenance of the child both regarding physical, mental health, and knowledge. With such a role, children will be avoided from all forms of the worst conditions that can be experienced by every child. So, it is very important to have prevention in the family, school and all parties.

The family is not only a place to educate but is expected to be able to create an atmosphere that encourages the motivation and success of students' studies. In educating children, parents must also be good teachers, the care and attention of parents will be very much more important for children from an early age, good parents are parents who are caring and understanding of their children's needs, becoming playmates when children need friends, because at this age the child needs more attention and a high level of care from his parents (Soejono, 2009).

Under normal circumstances, the first environment associated with a child is parents, older siblings, and close relatives who live together. Through this environment, children are familiar with the world around them and the patterns of interaction that apply daily, through the environment, children experience the initial socialization process. Parents, relatives, and closest relatives usually pay attention to educating children so that children get the basics of a true and good relationship. Children's behavior is very dependent on the way parents educate, parents who do not pay attention, provide positive guidance, and give good direction, then the child will grow into a child who does not get the full attention of parents. The family is the single most important push in supporting the success of children's education, because without the encouragement of the family the child will be a little difficult to undergo his education. Children's success is the happiness of parents and family.

Parents are actually the key to the motivation and success of children's education; no other party will be able to replace the role of parents. The success of parents in supporting the motivation and success of children's studies lies in the close relationship between parents and their children. Parents are a place for children to take shelter and get peace through harmony between order and peace, and considering the influences that come from outside the home.

Family factors on child development according to Ahmadi (2002) are as follows: 1) the balance of attention is the balance of attention of parents for their tasks, even for these tasks must be comprehensive. Each task requires full attention according to its portion. If this is not the case, an imbalance will occur. 
All that is imposed on parents as tasks are very much needed in the child's development. This means that children need family stability, education, physical and psychological care. If the attention of parents to the tasks is not balanced, it means that there is a need for children to develop that has not been fulfilled; 2) Family integrity that is a whole family is a family that is equipped with family members such as father, mother, and children. Conversely, a broken family or Broken Home occurs where one parent is absent due to death or divorce, or both are absent. Intact and broken families have different effects on children's development. The whole family is not only intact in the sense of the gathering of father and mother but intact in the truest sense, that is, in addition to being physically intact and also psychologically intact. The whole family has a parent's roundness to their children. The whole family has full attention to their duties as parents; 3) Parents' social status has an influence on their children's behavior and experience. What is meant by social status here is the position of people in the group; 4) The size of the family that is affecting the social development of children, large families have several children, while small families, family members are also few. Extended family is a family consisting of husband and wife and more than three children. Small families are families consisting of husband and wife and three or fewer children; 5) Rich/poor families are rich families that can provide material needs for their children. These material requirements are needed by children. From game equipment too expensive school equipment and clothing. Instead, children born to poor families. Unmaterial needs are not fulfilled, even if only minimally.

The concept of parental involvement is perhaps the most important thing. Teaching and setting an example by the teacher, the home helps parents and children develop effective teaching styles. Active participation of parents is very much that can be done by parents, among others: 1) Parents as caregivers/nurses provide support and encouragement to their children, the dependence of young children takes them in a daily role where they observe, decrease and learn from their parents; 2) Parents are consumers. They pay, directly or indirectly, for programs and services that their children receive. Most parents want to vote in what they teach their children, and they want to participate in the teaching of their children; 3 ) Parents, if they understand the program that their child is following, can be the best support for the continuation and expansion of the program. School boards, advisory boards and state lawmaking bodies for the entire United States have changed policy points and laws as a direct result of parental support; 4) Family support is a system that includes interactions and interventions that strengthen family unit unity; 5) Parents who have children generally have more responsibility for their children over a longer period of time than parents who have children who develop normally; 6) Parental involvement is really able to accelerate the level of learning of children the level of parental involvement is positively related to cognitive development (Roopnarine, 2011).

Children cannot be separated from the family, with families people can gather, meet and stay in touch. Can be imagined if humans live without family. Without realizing it indirectly, has eliminated the nature of a person as a social creature (Jailani, 2014). According to the Qur'an, children can be grouped into four typologies Ilyas (2007)

\section{Children as Living Jewelry in the World}

The Qur'an states that children are the jewels of life (Zinatu al-hayah ad-mundo), which means:

"Possessions and children are the ornaments of world life, but everlasting good deeds are better rewards at the side of your Lord and better to be hope" (QS. Al-Kahfi: 46).

Every person who is married would want to have children, in addition to being the successor in the future children also as a complement in the household. The Qur'an states that children are like adornments, in which children function to beautify a household. 


\section{Children as Exams}

In addition to being a world-class jewel, the child is also a test (slander) for both parents. Allah says: and this means:

"And know that your properties and your children are but a trial and that Allah has with Him a great reward." (QS. AlAnfal: 28).

Humans are sometimes neglected by the trust God has given them, one of which is the parent being tested in the presence of their child. With children they would neglect their duty as human beings to worship God and as parents to educate and guide their children.

\section{Children as Enemies}

Children can also be enemies to both parents. Allah says:

"O believers, Surely among your wives and your children there are enemies for you, so is careful of them" (QS. AtTaghabun: 14).

\section{Child as the Eye of Light}

This fourth type of Qur'an is called the Qurratu a'yun (the light of the eyes). Allah says: It means:

"And those who say, "Our Lord, grant us from among our wives and offspring comfort to our eyes and make us an example for the righteous." (QS. AlFurqan: 74).

Qurratu a'yun means light eyes, gems, very fun. This is the ideal child typology. These typological criteria include submissive and submissive to Allah Almighty, devout to parents, good to one another. Or with other expressions of faith, knowledge, and practice. Hablum minallah and hablum minannas work well.

\section{Child Obligations}

If the obligations of parents are fulfilled as a form of affection for the child, it is natural for a child to be kind to his parents. The obligation to do well to his parents basically the balance of the obligation of custody from the parents, who have been caring for children, from before birth to adulthood. The Qur'an states:

"And your Lord has decreed that you not worship except Him, and to parents, good treatment. Whether one or both of them reach old age [while] with you, say not to them [so much as], "uff," and do not repel them but speak to them a noble word." (QS, Al-Israa: 23)

"We command humans to do good to their two mothers and fathers, to conceive their mothers with difficulty, and give birth to them with difficulty (too). containing it until weaning is thirty months" (QS, Al-Ahqaf: 15)

Doing well to these parents is emphasized in Islam. As a manifestation, children have an obligation to provide for their parents, if indeed their parents need it. Because the property of the child is basically the property of his parents as well, as mentioned by the Prophet's hadith: Meaning: "As well as you eat what is from your business, and the child is one of the results of your effort, then eat (from your child's treasure) with good and delicious." (H.R. atTirmidzi from Aisha).

\section{Parenting Pattern towards children}

Children are entrusted and mandated by parents to be responsible to Allah SWT. Children are a place where parents express love; children are also a future hope for parents in the hereafter. Therefore parents must nurture, raise, care for, care for and educate their children with full responsibility and affection (Ilyas, 2007). Parents are the first foundation that determines the personality of the child, because parents have been faced by the child when he was a child until he was educated in a family (Armai, 2002).

Parenting means the way of care that is implemented by parents in the family as an expression of their love for their children. Parents as educators have enormous responsibilities in nurturing, coaching, and education, and this is a primary responsibility (Qadar Muhammad, 2011). 
Under normal circumstances, the environment associated with children is their parents, older siblings (if any), and possibly close relatives who live together. It is through this environment that children get to know the world around them and patterns of daily life that apply daily. Through this environment, children experience the initial socialization process. Parents, siblings, and closest relatives usually pay attention to educating children so that children get the basics of a correct and good lifestyle, through the inculcation of discipline and freedom and its fermentation. At this time parents, relatives and relatives do socialization that can be applied through love (Soejono, 2009).

Elizabeth B. Hurlock said that parents' attitudes affect the way they treat children, and their treatment of children conversely affects children's attitudes towards them and their behavior. Basically, the parent-child relationship depends on the attitude of the parents (Elizabeth B., 2000). Baumrid in Mahmud's quote categorizes parenting into three types, namely: authoritarian parenting, authoritative, and parenting permissive. The three types of Baumrid parenting are almost the same as the type of parenting according to Hurlock as well as Hardy \& Heyes, still in Mahmud's quote, namely: authoritarian parenting, democratic parenting, and permissive parenting (Mahmud dkk., 2013).

\section{Juveniles and the problems they face}

The word adolescent comes from the Latin adolescence which means to grow to reach maturity or in development into adulthood (Asrori \& Ali, 2006). Santrock dkk (2011) defines adolescence (adolescence) as a developmental period of transition between childhood and adulthood which includes biological, cognitive, and socio-emotional changes. Regarding vulnerable teenagers Santrock argues, early adolescents begin approximately 10 to 13 years and end between the ages of 18 to 22 years. Seeing the current state of things that have completely changed, the aspects of the child's personality are also influenced. Various problems arise and begin to be shown by children with the environment and when in the midst of society.
So with that, education for children must be more intense and disciplined, so as not to be carried away by the flow of the destruction of the times (Suparta \& Aly, 2003).

So many delinquents that occur in adolescents, causing various forms of harm to himself and others. Parents need to pay attention to the development of children both changes in attitude, how to act and must guide to the maximum. Delinquency that happens to students actually starts from trivial matters, such as defending friends, solidarity, revenge and so on (Hasballah 2003).

One phenomenon which is quite alarming is the large number of teenagers involved in brawls. This mostly happens in big cities that result in losses and even loss of life. Fighting by teenagers makes a bleak future even more than that. According Sarwono 2002) divides the factors that cause abnormalities in adolescents into two namely, environmental factors and personal factors.

Sarwono (2012) divides the form of juvenile delinquency into four types, namely: 1) Delinquency that causes physical casualties to others: fighting, rape, robbery, murder, and others; 2) Delinquency that causes material casualties: vandalism, theft, pick pocketing, extortion, and others; 3) Social delinquency does not cause casualties on the side of others: prostitution, drug abuse; 4) Delinquency that is against status, for example denying the status of a child as a student by ditching, denying the status of parents by running away from home or refusing their orders, and so on. While Willis (2012) said that there are several forms of delinquency committed by juveniles, namely: theft, fraud, fighting, vandalism, assault, robbery, narcotics, sexual violations, violations, killings, and other crimes. Juvenile delinquency, according to Sarwono, divides efforts in tackling juvenile delinquency into three ways namely, preventive efforts, curative efforts, coaching efforts (Sarwono, 2002).

Understanding the Forms of Juvenile Delinquency in Karang Tangah Village 
Along with the progress of the times and technology, various forms of delinquency committed by juveniles are not something that we are familiar with and we seeing together. The following is misbehavior committed by juveniles in the Karang Tangah village, Lengayang Subdistrict, Pesisir Selatan district of West Sumatra, including:

\section{Gambling (Ludo, Guessing the Score of a Soccer Match Team)}

Gambling is a normal phenomenon that occurs everywhere, is not a taboo anymore even some people considering it to be an ordinary problem. The phenomenon of gambling that occurred in the village of Karang Tangah, actually did not just happen, at first the teenagers and young people in this village only played ludo as usual to fill their free time at night. As we know, stalls or small shops in the village are always busy at night. However, over time the ludo game was made as a game that made decent money and profits.

The teenagers in the evening fill their free time by playing gambling conducted in stalls. Gambling is done through the ludo game that is on the cell phone. As it is known that the game ludo is indeed the current trends. This exciting and inspiring game is indeed interesting for teenagers to be a place for betting. Most who play ludo gambling are teenagers who are still in the first school and even some who are still in elementary school, those who should be at home and busy with learning activities but are in a place that is not beneficial to him

Next is guessing the score on the soccer team that will compete. Where this form of gambling is that each of them must pay his friend if they are correct in guessing the score of the match. The amount to be paid can reach 30,000 and even up to 50,000 , this gambling has long been happening among juveniles and the community as if they are making gambling as a place to look for income. This phenomenon has certainly been included in gambling which can damage the character of children and juveniles of course. It's sad indeed if this is left just like that, because it is not impossible if there is no full supervision from parents, the child will get used to the habit of gambling does.

\section{Liquor}

Advances in technology in various fields have made every region in Indonesia experience significant changes, both in the social, economic, trade and so on. Likewise, it is easy for everyone to buy and sell various kinds of products and transactions that provide convenience for everyone. One of them is liquor.

With the advancement of the KarangKarang village which has become a route for the southern and Bengkulu coastal routes, it has made it easier for certain traders and individuals to sell these illicit beverages. So that in some stalls selling liquor freely just like that. The phenomenon of adolescent drinking is just beginning to try and just fad. However, these teens gradually become addicted to consuming illicit drinks, they make liquor as a place of intimacy in friendship. Teenagers often buy liquor when there are big events such as the celebration of the organ after the Eid and they consume it together in stalls even in quiet places.

Delinquency and deviations that occur in the village of Karang Tangah seem like a habit that is difficult to change for the community and adolescents, because liquor is often the choice for youth and some irresponsible communities. Thus, adolescents also began to try and over time many of them were addicted to liquor.

\section{Theft and robbery}

Islam is one religion that strictly prohibits acts of theft or robbery. Of course, some people are so unhappy and restless about theft, even exceeding their hatred of adultery even though both are included in acts prohibited by religion.

\footnotetext{
"Ambo maraso ndak nyaman karano kini ala banyak adiak-adiak kito, remaja kito nan di kampuang tatangkok mencilok. Padahal ala jaleh dalam agama kito ndak dibuliahan muambiak barang urang
} 
karano itu indak punyo awak. Iko nan sabananyo paralu bana kito puatian sebagai masyarakat dan tokoh nan ado di kampuang supayo anak kapanakan kito $n d k$ ado yang mancilok dima-dima ajo lai"

Theft and robbery are one of the most despicable acts which can violate the norms that exist in society because it is not in accordance with the teachings of Islam. Progress of the times and increasing needs in meeting the needs of life enough to give some influence for juveniles. The proof is that some juveniles in Karang Tangah village were caught stealing outside the area. As a result, juveniles were caught by the police and had to deal with the law. This problem provides bad news for a hometown that is labeled ugly by some people. Surely this is a good joint evaluation of parents, community leaders and government in the village.

In the explanation above, how important is supervision of parents to children, especially in adolescents. Those who are in an unstable phase need very much attention from parents, the community and community leaders in the village. Parents should not be careless to pay attention to children, it is not always able to pay attention at any time, but take advantage of certain times by discussing and telling stories with children so that there is an attitude of kindness in the child.

\section{Family Efforts in Tackling Juvenile Delinquency in Karang Tangah Village}

Efforts made by the family especially the two parents in Karang Tangah village to prevent juvenile delinquency include: giving advice, reprimanding, scolding and giving punishment. The author considers the method used by parents as appropriate in educating children. However, the method given is only done in one step so that children / teenagers often ignore the warning from their parents. Moreover, children / adolescents are in a phase that is always changing, making them easy to return to deviations and delinquency.
Furthermore, parents do not give a good reflection to the child, so that children feel reprimand given by parents to themselves is just an ordinary thing without any element of change. Of course parents must show their authority to children so that they are consistent in educating children. The next problem is the limited knowledge of parents in educating children due to lack of knowing ways to educate children so that a situation occurs where children lack good character and personality formation.

This phenomenon is certainly a shared learning not only for parents who have long been married but also for someone who is going to have a family. Children / adolescents must be directed to become ideal human beings, to be stable in their behavior and to be educated to the maximum extent possible for their bright future and to be useful in the future. According to Nizar's quote to realize an ideal human being is a problem that must be solved together. This effort must of course start from the family environment then normally the school environment and the community take an active role in shaping the ideal human figure (Nizar, 2008).

\section{CONCLUSION RECOMMENDATION}

AND

Based on the explanation above, it can be concluded that the form of juvenile delinquency in Karang Tangah Village, Lengayang Subdistrict, Pesisir Selatan Regency, West Sumatra namely gambling (ludo), stealing / robbing, and drinking liquor. The form of delinquency done by these teenagers is due to the still weak supervision and attention of parents in educating them so that they are trapped in these deviations.

The efforts made by parents in preventing the delinquency of their children such as reprimanding, scolding and being assertive. However, the practice is still mediocre so that children are still showing bad behavior. Therefore, it is very important for family education which is a means of forming the identity of a good child, how he behaves and lives his role as a child so that he is ready to face the future. 


\section{REFERENCES}

Abdullah, M. I. (2003). Pendidikan Keluarga bagi anak. Cirebon: Lektur.

Ahmadi, A. (2002). Psikologi Sosial. PT Rineka Cipta.

Al Munawar, S. A. H. (2005). Aktualisasi Nilai-Nilai Qur'ani dalam Sistem Pendidikan. Ciputat Press.

Al-Hasyimi, M. A. (2004). Muslim Ideal. Yogyakarta: Mitra Pustaka.

Amani, A. (2018). PEran Guru Bimbingan Dan Konseling Dalam Memotivasi Belajar Siswa SMP N 15 Yogyakarta. Hisbah: Jurnal Bimbingan Konseling dan Dakwah Islam, 15(1), 20-34.

Armai, A. (2002). Pengantar Ilmu dan Metodologi pendidikan islam. Jakarta: Ciputat Pers.

Asrori, M., \& Ali, M. (2006). Psikologi Remaja: Perkembangan Peserta Didik. Jakarta: PT Bumi Aksara.

Aziz, A., \& Hartono. (2001). Ilmu Sosial Dasar. Bumi Aksara.

Aziz, S. (2015). Pendidikan Keluarga: Konsep dan Strategi. Penerbit Gaya Media Pratama.

Bafadhol, I. (2017). Pendidikan Akhlak Dalam Perspektif Islam. Edukasi Islami: Jurnal Pendidikan Islam, 6(02), 19.

Baharun, H. (2016). Pendidikan Anak Dalam Keluarga; Telaah Epistemologis. PEDAGOGIK: Jurnal Pendidikan, 3(2).

Berkowitz, M. W., \& Hoppe, M. A. (2009). Character education and gifted children. High Ability Studies, 20(2), 131-142.

Berns, R. M. (2004). Child, family, school, community: Socialization and support. United States of America: Thomson Learning. Inc.
Boonstra, H. (2001). Islam, women and family planning: A primer. The Guttmacher Report on Public Policy, 4(6), 4-7.

Brannon, D. (2008). Character education: It's a joint responsibility: instilling positive character traits in children requires teachers, parents, and administrators to work together. Kappa Delta Pi Record, 44(2), 62-65.

Corso, A. R. D., \& Lanz, M. (2013). Felt obligation and the family life cycle: A study on intergenerational relationships. International Journal of Psychology, 48(6), 1196-1200.

Damerell, P., Howe, C., \& Milner-Gulland, E. J. (2013). Child-orientated environmental education influences adult knowledge and household behaviour. Environmental Research Letters, 8(1), 015016.

Damon, W. (2004). The moral advantage: How to succeed in business by doing the right thing. Berrett-Koehler Publishers.

Departemen Agama RI. (2000). Al-Qur'an dan Terjemahnya. Diponegoro.

Departemen Agama RI. (2008). Membangun Keluarga Harmoni (Tafsir Al-Qur'an Tematik). Departemen Agama RI.

Eccles, J. S. (2005). Influences of parents' education on their children's educational attainments: The role of parent and child perceptions. London review of education, 3(3), 191-204.

Eccles, J. S., \& Roeser, R. W. (2009). Schools, academic motivation, and stage-environment fit.

Elizabeth B., H. (2000). Perkembangan Anak (terj. Med. Meitasari Tjandrasa). Erlangga.

Franceschelli, M., \& O'Brien, M. (2014). 'Islamic capital'and family life: The role of Islam in parenting. Sociology, 48(6), 1190-1206. 
Fransisca, C. (2009). Peran Partisipasi Kegiatan di Alam Masa Anak, Pendidikan dan Jenis Kelamin sebagai Moderasi Terhadap Perilaku Ramah Lingkungan [Disertasi]. Program Magister Psikologi Fakultas Psikologi Universitas Gadjah Madha.

Gee, J. P. (2000). Chapter 3: Identity as an analytic lens for research in education. Review of research in education, 25(1), 99-125.

Goode, W. J. (2007). Sosiologi Keluarga. PT Bumi Aksara.

Hasna, F. (2003). Islam, social traditions and family planning. Social policy \& administration, 37(2), 181-197.

Hein, G. E. (2005). The role of museums in society: Education and social action. Curator, 48(4), 357.

Ilyas, Y. (2007). Kuliah Akhlaq. LPPI.

Ira, H. (2008). Dasar-dasar kependidikan. UIN Alauddin. Makassar.

Jailani, M. S. (2014). Teori Pendidikan Keluarga dan Tanggung Jawab Orang Tua dalam Pendidikan Anak Usia Dini. Nadwa, 8(2), 245-260.

Jamison, M. A. (2005). Detention of juvenile enemy combatants at Guantanamo Bay: The special concerns of the children. UC Davis J. Juv. L. \& Pol'y, 9, 127.

Khayyal, M. M. A.-J. M. A. H. (2005). Membangun Keluarga Qur'Ani Panduan Untuk Wanita Muslimah. Amazah.

Kim, T.-H., Lee, S. M., Yu, K., Lee, S., \& Puig, A. (2005). Hope and the meaning of life as influences on Korean adolescents' resilience: Implications for counselors. Asia pacific education review, 6(2), 143152.

LESTARI, E. G., Humaedi, S., SANTOSO, M. B., \& Hasanah, D. (2017). Peran
Keluarga dalam Menanggulangi Kenakalan Remaja. Prosiding Penelitian dan Pengabdian kepada Masyarakat, 4(2).

Liñán, F., Rodríguez-Cohard, J. C., \& RuedaCantuche, J. M. (2011). Factors affecting entrepreneurial intention levels: A role for education. International entrepreneurship and management Journal, 7(2), 195-218.

Mahmud, A. A. H. (2000). Pendidikan rohani. Gema Insani.

Mahmud, Gunawan, H., \& Yulianingsih, Y. (2013). Pendidikan Agama Islam dalam Keluarga: Sebuah Panduan Lengkap bagi Para Guru, Orang Tua dan Calon. Academic Permata.

Mahmud, M. E. (2012). Motif Penyelenggaraan Pendidikan Islam dan Implikasinya pada Pola Manajemen dan Kepemimpinan. Dinamika Ilmu, 12(2).

Mansur, M. A. (2005). Pendidikan anak usia dini dalam Islam. Yogyakarta: Pustaka Pelajar.

Mincey, B., Maldonado, N., Lacey, C. H., \& Thompson, S. D. (2008). Perceptions of successful graduates of juvenile residential programs: Reflections and suggestions for success. Journal of correctional education, 8-31.

Mizal, B. (2014). Pendidikan dalam keluarga. Jurnal Ilmiah Peuradeun, 2(3), 155178.

Moleong, L. J. (2010). Metodologi Penelitian Kualitatif. PT Remaja Rosadakarya.

Mubarak, A. (2016). Psikologi Keluarga. Madani.

Muhammad, A. R. (2003). Pendidikan di alaf baru. Yogyakarta: Prismasophie.

Mukarrom, A. (2018). Islamic legal basis for marriage. Jurnal Kajian Hukum Islam, 5(2), 181-190. 
Muzaqi, I., Sarbini, M., \& Maulida, A. (2019). Upaya Mudarris Dalam Mengajarkan Pendidikan Akhlak Yang Terkandung Pada Surat AlHasyr Dalam Kehidupan Keseharian Santri (Studi di Pondok Pesantren AnNur Sukamantri Bogor). Prosa PAI: Prosiding Al Hidayah Pendidikan Agama Islam, 1(2B), 203-214.

Nashuddin, N. (2015). Early-age Marriage in Perpective of Indonesian Islamic Family Law. Al-Mawarid Journal of Islamic Law, 15(2), 97-122.

Nizar, S. (2008). Memperbincangkan Dinamika Intelektual dan Pemikiran Hamka Tentang Pendidikan Islam. Kencana.

Pamungkas, M. I. (2012). Akhlak Muslim Modern: Membangun Karakter Generasi Muda. Bandung: Marja.

Qadar Muhammad, Y. (2011). Tafsir Tarbawi. Zanafa Publihing.

Qaimi, A. (2002). Menggapai langit masa depan anak. Bogor: Cahaya.

Ramayulis, I. P. I. (2001). Metodologi pengajaran agama Islam. Jakarta: Kalam Mulia.

Reinke, W. M., Splett, J. D., Robeson, E. N., \& Offutt, C. A. (2009). Combining school and family interventions for the prevention and early intervention of disruptive behavior problems in children: A public health perspective. Psychology in the Schools, 46(1), 3343.

Reynolds, C. R. (2010). Behavior assessment system for children. The Corsini encyclopedia of psychology, 1-2.

Roesli, M., Syafi'i, A., \& Amalia, A. (2018). Kajian islam tentang partisipasi orang tua dalam pendidikan anak. Jurnal Darussalam: Jurnal Pendidikan, Komunikasi Dan Pemikiran Hukum Islam, 9(2), 332-345.
Romlah, M. P. I. (2016). Manajemen pendidikan islam. Harakindo Publishing.

Roopnarine, J. L. (2011). Pendidikan Anak Usia Dini Dalam Berbagai Pendekatan. Kencana.

Santrock, J. W., MacKenzie-Rivers, A., Leung, K. H., Malcomson, T., Bohlin, L., Durwin, C. C., \& Reese-Weber, M. (2011). Nature of Adolescence: Bachelor of Education Course (intermediate/secondary): ED 4260. McGraw-Hill Custom Publishing.

Sarwono, S. W. (2002). Psikologi Remaja. Raja Grafindo Persada.

Semba, R. D., de Pee, S., Sun, K., Sari, M., Akhter, N., \& Bloem, M. W. (2008). Effect of parental formal education on risk of child stunting in Indonesia and Bangladesh: A cross-sectional study. The lancet, 371(9609), 322-328.

Silverstein, M., Gans, D., \& Yang, F. M. (2006). Intergenerational support to aging parents: The role of norms and needs. Journal of family Issues, 27(8), 1068-1084.

Soejono, S. (2009). Sosialisasi Suatu Pengantar. Rajawali Persada.

Sudjana, D. (2004). Manajemen program pendidikan. Bandung: Falah Production.

Sudrajat, A. (2011). Membangun budaya sekolah berbasis karakter terpuji. Jurnal pendidikan karakter UNY.

Suparta, H. M., \& Aly, H. N. (2003). Metodologi Pengajaran Agama Islam. Amissco.

Syarifuddin, A. (2006). Hukum Perkawinan Islam di Indonesia (Antara Fiqh Munakahat dan Undang-undang Perkawinan). Kencana Prenamedia Group.

Taubah, M. (2015). Pendidikan Anak dalam Keluarga Perspektif Islam. Jurnal 
Pendidikan Agama Islam (Journal of Islamic Education Studies), 3(1), 109136.

Thomas, L. (2002). Student retention in higher education: The role of institutional habitus. Journal of education policy, 17(4), 423-442.

Van Zanten, A. (2005). New modes of reproducing social inequality in education: The changing role of parents, teachers, schools and educational policies. European Educational Research Journal, 4(3), 155-169.

Walgito, B. (2010). Bimbingan dan konseling (Studi dan Karir). Yogyakarta: $C V$ Andi Offset.

Walker, S. C., Bishop, A. S., Pullmann, M. D., \& Bauer, G. (2015). A research framework for understanding the practical impact of family involvement in the juvenile justice system: The juvenile justice family involvement model. American Journal of Community Psychology, 56(3-4), 408-421.

Willis, S. S. (2012). Remaja dan Masalahnya: Mengupas Berbagai Bentuk Kenakalan Remaja, Narkotika, Sex, dan Pemecahannya. Alfabeta.

Wößmann, L. (2003). Schooling resources, educational institutions and student performance: The international evidence. Oxford bulletin of economics and statistics, 65(2), 117170.

Yüksel, H., \& Coşkun, A. (2013). Strategy focused schools: An implementation of the balanced scorecard in provision of educational services. ProcediaSocial and Behavioral Sciences, 106, 2450-2459.

Yusuf, S. (2009). Psikologi Perkembangan Anak dan Remaja. PT Remaja Rosadakarya. 